CAE Working Paper \#03-04

Globalization and the Politics of International Finance:

The Stiglitz Verdict

by

Kaushik Basu

May 2003 
May 2, 2003

\title{
Globalization and the Politics of International Finance: The Stiglitz Verdict
}

by

\author{
Kaushik Basu \\ Department of Economics \\ Cornell University \\ Ithaca, NY 14853 \\ Fax: 6072552818 \\ Email:kb40@cornell.edu
}

Acknowledgements: I am grateful to Mrinal Datta Chaudhuri, John McMillan, Patrick Nolen, Erik Thorbecke, and Henry Wan for comments and discussions. 


\section{Globalization and the Politics of International Finance: The Stiglitz Verdict [A review article on Joseph Stiglitz: Globalization and Its Discontents, Norton \& Co.,} New York, 2002.]

\section{Introduction}

Joseph Stiglitz's recent book, Globalization and Its Discontents (2002) defies easy categorization. It is, in part, an academic monograph meant to be read by professional economists and the serious graduate student; but it is also, in part, a diatribe against the injustices of global finance and politics. It is written at times from the ivory tower, contemplating the vast panorama of international economic relations with a researcher's trained but distant vision; but it also reads in places like a rabble-rousing call from an activist who has no time for the niceties of models and regressions. With a title that rhymes with Sigmund Freud's classic monograph, this too is a book where an academic, who has done pioneering work in his field, cuts loose from the binds of his discipline and assesses the world with passion, concern and also disappointment.

It is the disappointment that makes this such a compelling book. Stiglitz has seen it all. In 1993 he moved out of the groves of academe to join President Clinton's Council of Economic Advisers ${ }^{1}$. From there he went to the World Bank as Senior Vice President and Chief Economist. Popular globally for championing the cause of the disadvantaged and dispossessed and for not holding back on criticizing the U.S. Department of Treasury and the IMF, he became unpopular in the bastions of power in Washington for the very same reasons. Soon after leaving the World Bank and joining Columbia University he won the Nobel Prize in economics, shared with George Akerlof and Michael Spence. He

\footnotetext{
${ }^{1}$ Initially, as Member, and then, from 1995 to 1997, as Chairman.
} 
himself has little to be disappointed about in the world. And that is exactly what gives poignancy and moral force to his disappointment, and strength to his argument.

Moving from the world of theoretical models and the study of market equilibria, he encountered in Washington a world of finance and markets, which did not correspond to the theoretical constructs of modern economics. This was true even when one considered the most realistic theoretical models, which broke ranks with the orthodoxy of the so-called traditional 'Chicago School' and allowed for imperfect information, multiple equilibria and Pareto sub-optimality. Moreover, not only was reality less perfect than these models, it was more unfair. Of course, the unfairness works to the advantage of the strong and the powerful and the ones who side with the establishment. This book is Stiglitz's breaking rank with the establishment.

There are many 'outsiders' who have written critiques of globalization and the global financial system. Insiders typically do not do so; they have too much to lose. It is this recklessness that makes the book effective. This is so in the same way that Soros' (2002) critique of U.S. hegemony and the unfairness of market fundamentalism makes compelling reading because his recommendations stand at variance from his interests. Another strength of the book stems from the fact of Stiglitz's command over the length and breadth of economics. So, while he lashes out at market fundamentalism, he is fully aware of and never down plays the importance of markets and incentives. Likewise, while he points to all the negative fall-outs of globalization and how it has marginalized so many people, communities and nations, he shows awareness of the ways in which globalization can confer benefits on the poor. In fact, he makes it clear that he is no anti-globalizer. He is fully cognizant of the benefits of trade and global capital flows. 
This is a book that can be read profitably by both the defenders of market fundamentalism and the demurrers of globalization.

Despite all these strengths, the book fails to live up to its expectations in some important dimensions. Some of these have to do with the minor nuts and bolts of Stiglitz's argument - I shall comment on those when I come upon them. A more major disappointment stems from the fact that, while the book breaks away from so many orthodoxies and builds up expectation for a new alternative vision, it does not attempt to deliver on that.

Barring a few readers, steeped in prejudice, most will agree with the broad contours of Stiglitz's criticism of global politics and orthodox economics. But in the wake of this criticism the natural question that arises is: how then should one think of markets and economies, and what should be the paradigm that one carries in one's head when thinking of global political economy? With a lesser author one would be wrong to even ask these questions. It should be deemed enough if the author managed to raise doubts about the orthodoxy. But given that Joseph Stiglitz has in the past dislodged parts of orthodox economics and rebuilt new models in their place, one naturally hoped for a little bit of the latter in this book; but on that score one is left disappointed.

\section{Facts, Theories and Myths}

In many dimensions modern economics has had phenomenal success. On a variety of subject matters there are excellent models - theoretical constructs that help us think through what the consequences of certain actions will be. Thus, if following the Iraq War, oil supplies to the world increase, we know that the price of travel will fall. 
We do not need empirical knowledge of previous experience with the rise and fall of Iraqi oil supplies to make this prediction. We make the prediction using the model of demand and supply, which is founded on a few basic 'truths' (which are admittedly empirical), and then applying a chain of deductive reasoning based on that.

There are other areas, where we have little or no theory to go by, but have enough evidence to make intelligent guesses about how one action may affect another.

But despite the much-vaunted success of economics in many areas, economics remains remarkably weak on some of the most important questions that confront nations. What causes an economic crisis, such as the one that affected most of East Asia in 1997 ? And what is the remedy when such a crisis occurs? How does politics intertwine with markets? What kind of political system helps economic growth and what kind hinders?

If we search through the textbooks of economics and the tomes of data at our disposal, we will be forced to admit that we have very little to go by when taking on such questions. But we are, nevertheless, often forced to give answers. An international organization, such as the IMF or the World Bank, whose job it is to help nations in economic trouble, cannot keep quiet when such troubling questions are asked. So they give answers, and through a process of herd behavior, the answers converged to what seemed like a consensus. Nations must privatize, cut fiscal deficit, curtail subsidies, remove trade barriers, and allow the free flow of international capital. This broad package came to be known as the 'Washington Consensus'. ${ }^{2}$

\footnotetext{
${ }^{2}$ For a discussion of the Consensus and Stiglitz's position on this see Chang (2001).
} 
It will be unwise to think of the Washington Consensus as a product of conspiracy $^{3}$. It emerged from serious economists searching for the 'best practices' in an uncertain world, international organizations shirking from having to say "We do not know" and other unintentional acts. But, at the same time, it survives because it fits well with vested interests; it does not upset the apple cart.

The etymology of the term 'Washington Consensus' is interesting. What has come to be known by that term today is a bit of a caricature of the original. The term was, probably, first used by John Williamson in 1989 to describe a policy agenda, specifically, for Latin America. As he points out in a lucid, recent essay (Williamson, 2003), he was aware, even then, that the agenda omitted important objectives, such as a concern for better income distribution. His aim, at that stage, was to sketch a minimal agenda that would be acceptable to Washington. It was never meant to be a complete policy manifesto for all countries, or even all developing countries. But, over the years, it got seized upon by politicians and bureaucrats wanting to push a particular policy manifesto, and in the popular mind Washington Consensus came to be associated with this.

However, given that the Washington Consensus is not a formal document or an agreement, it is right to treat it now as what people take it to be. Hence, Stiglitz is right to direct his critique of this caricatured version of the Consensus rather than the original.

Stiglitz lived in Washington during the years of the East Asian and Russian crises of the nineties, and the heydays of transition in former socialist economies. And he grew

\footnotetext{
${ }^{3}$ Conspiracy theories are troublesome. Many lay persons see more conspiracies than there are, if only because human beings are congenitally prone to believing that someone's volition must be involved whenever they see order. In reality, Krugman (1998) is right when he asserts that he is disinclined to believe in conspiracy theories because, from what he had seen of world leaders, "they seem a lot like the rest of us: Most of the time they haven't got a clue". On the other hand, we must not be so naïve as to treat all order as spontaneous order. As Krugman observes in the same article, "Yet conspiracies do happen."
} 
disillusioned with the Washington Consensus. As he pushed hard to modify it, he realized that what gradually emerged as the Consensus may have been a product of serious soul searching, but interests had developed around it and in it. Much of this book is about the discovery of how myths get etched into institutional consciousness as facts and are then defended by established interests.

The easy way to defend a disputed idea is not to open it up for debate and to keep one's true findings and doubts in the closet. So a natural concomitant of this is a lack of transparency. And Stiglitz is right to argue that, over the years, the IMF has come to have too little transparency. On some matters he takes too strong a position against the IMF, as we shall see when we come to a discussion of the East Asian crisis.

\section{East Asian and Russian Crises}

The book has a large thesis: Globalization can potentially benefit all, but it has not done so. Those who are at the helm of global politics and economics have made sure that their wealth gets amassed and their power is protected. This has worked to the detriment of masses of people and regions that have got marginalized. The micro markets for wheat and rice may work entirely according to the laws of demand and supply, but the larger facts of economic life respond as much to politics and power as demand and supply, thereby casting doubts on our textbook theorems of market efficiency and optimality.

Stiglitz treats the East Asian and Russian crises of the late nineties as case studies in support of his thesis. On July 2, 1997, the Thai baht, after trading for ten years around 25 to a dollar, depreciated overnight by $25 \%$. No one knew at that time that this was the 
start of one of the greatest economic crises since the Great Depression. The crisis would soon spread to Malaysia, Korea, the Philippines and Indonesia. Over the next several months, these currencies would continue on a free fall, as shown in Table 1.

\section{Table 1}

Devaluations and Share Price Collapse, July 1, 1997 to February 16, 1998

\begin{tabular}{|l|c|c|}
\hline & $\begin{array}{c}\text { \% Depreciation of Currency } \\
\text { vis-à-vis the dollar }\end{array}$ & $\begin{array}{c}\text { \% change in the share } \\
\text { price index }\end{array}$ \\
\hline Thailand & $87 \cdot 09$ & -48.37 \\
\hline Malaysia & $55 \cdot 43$ & -58.41 \\
\hline Korea & $83 \cdot 04$ & -63.06 \\
\hline Philippines & $51 \cdot 37$ & -49.17 \\
\hline Indonesia & $231 \cdot 00$ & -81.74 \\
\hline
\end{tabular}

Source: Bloomberg Financial Services L.P., and Bank of Mexico. Reproduced in Martinez (1998).

The start of the crisis may have been inevitable but for its persistence, depth and consequent human suffering Stiglitz places the blame directly on the IMF and he does so with no holds barred. The problem, according to Stiglitz began early, when the "IMF and the U.S. Treasury seemed to criticize the countries - according to the IMF, the Asian nations' institutions were rotten, their governments corrupt, and wholesale reform was needed"(Stiglitz, 2002, p. 90).

There were many commentators who criticized the IMF for having failed to predict such a major crisis. Indeed there seemed to have been no one who predicted this. I had, some way into the crisis, researched through several weeks of old issues of the Economist and other magazines preceding the crisis. There were indeed no forewarnings; 
the Thai baht's fundamentals were described repeatedly as robust. The only mild criticism for East Asia was for its banking system and burgeoning non-performing assets. But failure to predict the crisis cannot be reason for criticism. It is, in fact, arguable that there is a logical problem in there existing anyone who is known to be able to predict a currency collapse in advance. It is not that no one can know well in advance that a currency will collapse. It is simply that no one can be known to know that.

To see this, suppose that there is an institution or a person who, through research or intuition, gets to know a month in advance when a currency is going to collapse. If now he is known to have this forecasting power, every time he makes such a forecast speculators will immediately sell the currency that he predicts will collapse after a month. That will cause the currency to collapse immediately. So he will never be able to make a public forecast of a collapse well in advance.

Stiglitz is too clear-headed a thinker not to realize this and he never criticizes the IMF for its failure to predict the crisis ${ }^{4}$. His criticism is directed at IMF's assertion, in retrospect, that it knew this had to happen some time because these East Asian nations were managing their economies so poorly, and the fact that the IMF then moved rapidly to put in place its standard reform package rooted in the Washington Consensus: These economies would have to raise interest rates, cut deficits, stabilize their economy and privatize.

This policy prescription, according to Stiglitz, exacerbated the problem. The IMF's big mistake was its failure to realize that the East Asian crisis was different from

\footnotetext{
${ }^{4}$ The IMF's failure to sound a warning on Korea, after Thailand, Indonesia and Malaysia went into crisis was, however, disappointing. Blustein (2001, p.118) has quoted from a confidential IMF document, dated as late as October 15, 1997, which observed that Korea's fundamentals were so strong that "we have
} 
crises seen in other parts of the world; and also that the global economic situation had changed quite drastically since the big international debt crisis of Latin America in 1982. Michael Camdessus was right in a sense when he described the East Asian crisis as the first financial crisis of the twenty-first century. But the response of the organization he headed did not reflect a proper understanding of this.

There were indeed, several important dimensions in which the world economy had changed. The most important is economic globalization. It is true that the world has been globalizing, in the sense of becoming more connected, ever since the dawn of human history. When the first humans moved out of Africa, when Amerigo Vespucci landed in the New World more than 500 years ago, and when Vasco da Gama landed in Cochin around the same time, these were all steps towards globalization. But there can be no denial that after a brief retreat between the two World Wars, the pace of globalization gathered pace like never before. This is true on two particular dimensions, capital movement, and trade. This is captured well in Table 2A and 2B.

Trade has increased very sharply in all major regions of the world, no matter how one measures this - in absolute terms or as percentage of GDP. If one goes further back into history one finds that in the entire hundred years from 1500 to 1600 , there were 770

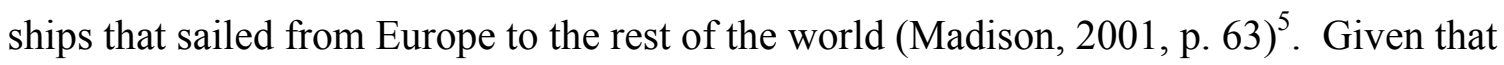
barring a trickle over land there were in those times no other mode of trade, it is evident

confidence in the authorities' ability to prudently manage the situation". The report was, subsequently, quietly put away in the Fund's files.

${ }^{5}$ Actually, this figure that Madison quotes is of ships that sailed from the 7 most major European countries. But given that there were no other serious maritime nations at that time, this would be pretty much the bulk of total transcontinental ship travel in the world. In addition, interestingly, of these 770 ships, 705 were from Portugal alone. 
that in terms of the sheer flow of goods, services and electronic material, the world has come a very long way.

Table 2A. Merchandise Export as \% of GDP

\begin{tabular}{|l|c|c|c|c|}
\hline & $\mathbf{1 8 7 0}$ & $\mathbf{1 9 1 3}$ & $\mathbf{1 9 5 0}$ & $\mathbf{1 9 9 5}$ \\
\hline Western Europe & 8.8 & 14.1 & 8.7 & 35.8 \\
\hline Asia & 1.7 & 3.4 & 4.2 & 12.6 \\
\hline Latin America & 9.7 & 9.0 & 6.0 & 9.7 \\
\hline Africa & 5.8 & 20.0 & 15.1 & 14.8 \\
\hline World & 4.6 & 7.9 & 5.5 & 17.2 \\
\hline
\end{tabular}

Table 2B. Value of Foreign Capital Stock in Developing Countries (\$ billion and \%)

\begin{tabular}{|l|c|c|c|c|}
\hline & $\mathbf{1 8 7 0}$ & $\mathbf{1 9 1 4}$ & $\mathbf{1 9 5 0}$ & $\mathbf{1 9 9 8}$ \\
\hline Total (in 1990 prices) & 40.1 & 235.4 & 63.2 & $3,030.7$ \\
\hline Stock as \% of GDP & 8.6 & 32.4 & 4.4 & 21.7 \\
\hline
\end{tabular}

Source: Madison (2001)

Regarding capital flows, as a percentage of GDP there has not been a monotonic rise. But the absolute amount of capital flow has risen dramatically. In addition, it has to be kept in mind that in colonial times, while capital did move from one nation to another, typically, capital flows had to be preceded by the flow of army, which would take political control of the colony to which the capital was being directed. The capital of the last two or three decades, on the other, is much more footloose, flowing in and out of countries over which the sender of capital may have no political control. Also, important 
to note in this context is the fact that a lot of the international capital was flowing into the stock markets of East Asia.

Another major difference between East Asia of the nineties and other regions and even East Asia of some decades ago, is their high savings rate: All the East Asian economies save over $30 \%$ of their national income. Under these circumstances there was no need for full capital account liberalization. This, according to Stiglitz, was "the single most important factor leading to the crisis" (p. 99). Many economists such as Jagdish Bhagwati, who, on trade matters, take a complete free market position, nevertheless take a line on capital account liberalization which is similar to that of Stiglitz ${ }^{6}$. Ironically, even as I write, the Washington administration is once again pushing for the abolition of capital controls ${ }^{7}$, unmindful of the warning by many economists that trade in goods must not be equated with capital flows (see Bhagwati and Tarullo, 2003, Wan, 2003). ${ }^{8}$

Whatever was the precise cause of the crisis, Stiglitz argues that the failure to appreciate the new reality and the use of the old standard IMF package backfired in East Asia. It is a theoretically elegant analysis that Stiglitz puts forward in his book.

A standard policy response to crisis that had been used time and again in Latin America consisted of controlling excess demand (by, for instance, cutting government

\footnotetext{
${ }^{6}$ A more disaggregated analysis would emphasize that the problem is not with the overall volume of capital flows but with its composition. A study by Rodrik and Velasco (1999) shows that a country with short-term liability to foreign banks that exceed its foreign reserves is three times as likely to have a sudden outflow of capital.

${ }^{7}$ This is part of the free trade agreements being negotiated by the U.S. with Chile and Singapore. What these countries wanted was not capital controls but the freedom to use capital controls in certain contingencies. But in the end they relented under pressure from the U.S. negotiators.

${ }^{8}$ For one, the capital market (unlike the market for goods) seldom takes the form in which an agent can borrow as much as she wishes at the going interest rate. Moreover, a person demanding capital is, typically, asked by the lender to explain why she needs the money. The greengrocer, on the other hand, does not ask you why you want the oranges before he agrees to sell you some.
} 
expenditure) and raising interest rate. Both these policies, Stiglitz argues, were wrong for East Asia, and were prompted by a crucial misdiagnosis of the crisis.

As an aside, it is worth noting that for this same reason, Stiglitz's brief analysis of Argentina is less convincing. It is not clear that the contractionary policy recommended by the IMF to Argentina was wrong. Argentina's government, struggling to compete with Brazil, with its exchange rate policy frozen under a Currency Board, was in a bind. Moreover, in the late nineties, it repeatedly missed its tax revenue targets, which made expenditure cutbacks that much more necessary.

Controlling excess demand is right policy for a nation suffering from inflation or repressed inflation. In East Asia there were no inflationary pressures in 1997 and the economies had reasonable macro-balance, including low fiscal deficits. Under those circumstances cutting government expenditure was likely to exacerbate a recession instead of aiding in its abatement.

The second policy instrument--that of raising the interest rate--is often used to bring foreign currency into the country (lured by the high interest rate) and thereby stall exchange rate depreciation. In East Asia this policy backfired for an interesting reason. While the governments of these countries had balanced budgets, the corporate sector, including small firms, was heavily indebted. When interest rates were suddenly raised in Thailand (and the same policy pattern would follow elsewhere) this may have temporarily shored up the demand for bahts but it meant that the highly leveraged Thai firms were driven to bankruptcy. ${ }^{9}$

\footnotetext{
${ }^{9}$ This argument of Stiglitz finds support from a detailed computable general equilibrium model of Indonesia that has been developed by Azis, Azis and Thorbecke (2001). By running simulations with alternative policy interventions, in particular, one where the intervention deviated from the actual IMF one by holding interest rate at a lower level, the authors found evidence that the IMF policy did exacerbate
} 
Much has been written about 'contagion' and 'infection' in discussing economic crisis and the often-mysterious process by which a crisis transmits from one country to another. Another important product of globalization that has not been written about adequately is what may be described as 'market contamination', namely, the process by which a crisis in one market or sector transmits to another. Market contamination is a product of the kind of globalization described above.

To continue with the Thailand example, note that as companies began to go bankrupt the stock prices, naturally, started to fall. This meant that people began selling off their stocks. In earlier times when currencies did not flow across borders with alacrity, this crisis could remain contained. But nowadays with such large capital flows across nations it is reasonable to expect that a part of the stocks traded on the Bangkok stock exchange will be by foreigners. It follows that with stock prices collapsing, as people sell off stocks, some of those selling the stocks will be foreigners (non Thailand residents). Since these people would typically have converted their currencies (dollars, euros, yens...) into Thai bahts, originally, in order to buy stocks in Bangkok, when they sell their stocks and collect bahts it is natural to expect they will convert the bahts back to their own currency. Hence, a fall in stock prices would now have a direct impact on the foreign exchange market causing the baht to devalue. Once the foreign exchange market gets destabilized, this will tend to rapidly contaminate other markets ${ }^{10}$.

\footnotetext{
some of the suffering. It is worth noting here that a recent theoretical exercise by Aghion, Bacchetta and Banerjee (2001) puts the credit shortages faced by private firms, instead of macro imbalances at the level of government, at the center of the model in explaining currency crises. In this sense, it is close to Stiglitz's description of the East Asian crisis. However, they find that, typically, raising the interest rate may be the right policy and one that can stall a crisis.

${ }^{10}$ The contamination of one market by another is illustrated well in Table 1. In each of the East Asian crisis country, at least in the early stages, the collapse of the currency was matched by the collapse of share prices. In many of these nations, land and property prices also collapsed around the same time.
} 
To return to the epidemiological analogy and to steal a macabre insight from the SARS epidemic, note that some markets are more effective at spreading trouble than others. Just as there was Typhoid Mary in 1907, and some people have been identified as 'super-infectors' in the spread of SARS, some markets are better than others at spreading contamination. Clearly the foreign exchange market is a 'super-infector' since it underlies so many other activities. This is especially so given globalization. To understand this, note that, if the baht is expected to fall, foreigners, who had bought stocks in Thailand or property in Thailand and measure their profit in dollars will have some reason to sell off their stocks (even though stock prices are not expected to fall) and then of course they will sell off the bahts thus acquired. Likewise for property. Hence, now stock prices and property prices will begin to collapse though nothing had happened in the stock market or the housing market to warrant this.

This is what happened in East Asia. The contamination traveled from one market to another and the echoes returned to worsen the initial crisis. And soon the contagion caught on in other countries.

One problem with Stiglitz's analysis of the East Asian crisis is that he gives too little benefit of doubt to the IMF. While he is right to be heavily critical of IMF conditionalities, its lack of transparency and its lack of adequate concern for poverty ${ }^{11}$, one is left wondering how the IMF could have been so systematically on the wrong side on so many decisions. And Stiglitz is ambiguous on an important question that naturally

\footnotetext{
${ }^{11}$ In fact one of the beneficial by-products of Stiglitz's hard-hitting criticism of the IMF is that it has now instituted programs to monitor the consequences of IMF stabilization programs for the poor. I have argued in Basu (2001) that international organizations should move towards evaluating nations in terms of the performance of their poorest $20 \%$ of the population. Apart from the fact that such a measure has some attractive technical properties, it should over time help tilt our aims in favor of the most disadvantaged.
} 
arises from his analysis: Were the IMF's mistakes instances of malfeasance or just bumbling?

In places he suggests that the IMF represented Wall Street's interests mediated through the Treasury, even when it was working ostensibly to help poor nations. "While Wall Streeters defended the principles of free markets and a limited role of government, they were not above asking help from government to push their agenda for them. And we shall see, the Treasury Department responded with force" (p.102). And the US with over $17 \%$ of the votes in the IMF worked hard to "help the special interests of Wall Street".

But there are other times when he seems to say it was not a case of malfeasance but ignorance on the part of the IMF. "Only if they had better economists", he seems to be suggesting. But if the IMF were representing special interests, having better economists would not make them more receptive to the concerns of developing countries but simply more effective in serving the special interests ${ }^{12}$.

I believe that in subtle ways the big powers do take control of the major international organizations and defend certain policies and ideas that are convenient to them. But they do this, often, not by directly twisting the agenda, but settling into an ideology and promoting ideas that are compatible with their interests. This is not hard because, as we discussed above, economics has had some major successes but remains woefully inadequate on many of the most important questions that confront policymakers. In these latter areas, it is easy for myths to develop. By repeating certain propositions sufficiently often they can be made to sound like facts and, given the

\footnotetext{
${ }^{12}$ Hence, the question, "Why did the best and the brightest fail?", does not seem to me to be a particularly interesting. They may not have been trying to do what we thought they were trying to do. Also, the best and the brightest can be locked in games like the Prisoner's Dilemma among themselves, and so may end up doing badly even for themselves.
} 
credibility of economics in other areas, most people treat as facts. This creates scope for subversion, feeding people with 'facts' which are convenient to some. The British satirical magazine, Private Eye, responding to the obsession of some American magazines to repeat-check facts, had once asserted how they, on the other hand, ran on the principle that "some facts are too good to be checked"13. The powerful do precisely that. The critical eye is turned away from myths, which are convenient to influential groups and powerful nations--Stiglitz’s “Wall Streeters”, big corporations and well-organized lobbies_- and in the process they get perpetuated.

The fact that economics has no real hard answers to the questions that countries face during a crisis, makes it possible for the IMF to behave the way it does. But this also means that the sort of policies that the IMF propounds is not egregiously or obviously false (see footnote 6). The IMF's fault is not that it recommended what is known to be false, but that it recommended in a tone of certainty on matters on which existing expert opinion is divided.

On balance, I do feel persuaded by Stiglitz that the IMF recommendations were flawed in East Asia; but the impossibility of doing a counter-factual experiment will mean that this will remain an open question. The IMF has maintained that the East Asian crisis was short-lived because of its policies. On the other hand, Stiglitz and other critics of the IMF have argued that the crisis was so deep because of IMF policies. The state of our current knowledge of economics is such that a full resolution of this is not possible.

In the case of some of the bigger countries the IMF has actually, unwittingly, played a useful role. When India had its economic crisis and had to turn to the IMF for

\footnotetext{
${ }^{13}$ Quoted from Sarah Lyall's essay, 'Recipe for Roasting the Sacred Cow, Tastelessly', New York Times, November 12, 2001.
} 
support in 1991, the Indian government managed to use the alibi of IMF pressure to push in some essential reforms ${ }^{14}$ which otherwise may not have been possible because of political constraints.

Also the IMF is probably less of a monolith than what Stiglitz seems to suggest. Thus he talks of "the IMF had feared", "the IMF felt", “the IMF opposed”. But there are, invariably, many opinions within such a large organization. I had witnessed this during my one year in the World Bank, in 1998-99. On a variety of matters (certainly on child labor) the research going on in the Bank was of a high quality and the opinions being expressed in many of these works were at variance with what the higher echelons of the Bank did or said, thereby showing that on many of these matters to talk of "the World Bank's view" would not make much sense ${ }^{15}$.

Stiglitz is on stronger ground on Russia because here he dwells a lot on cases where there were problems of corruption and attempts by the business mafia to twist policy to their own benefit. The crisis that hit Russia in the late nineties was quite dramatic. During 1940 to 1946 in Soviet Russia industrial production fell by $24 \%$. In 1990 to 1999 industrial production fell by 60\% and GDP fell by 54\%. As Stiglitz noted, "For the majority of those living in the former Soviet Union, economic life under capitalism has been even worse than the old Communist leaders had said it would be" (p.133).

\footnotetext{
${ }^{14}$ In fact much of the Indian reforms would be broadly in keeping with what Stiglitz would recommend. ${ }^{15}$ This also reveals that smart institutions have a way of dealing with a variety of opinions within the organization without silencing them and, at the same time, not allowing them to interfere with what the institution does. When I was a kid, growing up in Calcutta, and an unwanted kid came along and tried to join us, we would whisper into one another's ears the words "ele bele". An ele bele, in colloquial Bengali, is a person who thinks he is participating, but is not taken seriously by the real participants. It seems to me now that that was useful training since so many reputedly democratic organizations manage to maintain that reputation only by making its grassroots participants believe that they are participating.
} 
In Russia the tragedy was that Communism gave way into the hands of venal and corrupt profiteers. The new owners of formerly state-owned enterprises looted the companies, literally selling off company assets to stash away the loot in their private accounts. Some of the privatization programs were run very badly, and surely the IMF knew better. As Stiglitz observed, "It is easy to privatize quickly if one does not pay any attention to how one privatizes: essentially give away valuable state property to one's friends" (p. 144).

The immediate benefit of privatization is to increase efficiency and there is evidence that this does usually happen ${ }^{16}$. There is however a quandary about how firms are privatized that has to be kept in mind. If the state-owned firms are sold off at cut prices, as happened in Russia, basically one is making a gift to the buyer. Since such a gift is not always visible to the lay public, this gives rise to corruption, with politicians effecting quid pro quo trades with business people. On the other hand, if the state-owned firms are sold at their full market price, then this act of privatization, in itself, does not amount to a transfer of wealth from government. It merely amounts to a re-composition of government portfolio. In that case, much depends on what is done with the money that is acquired by government after the sale. If the government uses it to acquire control over some other resource, which it is not good at managing, then this privatization need not yield any benefit.

Since the purpose of privatization is to diminish government control over ordinary market activity, one essential feature of successful privatization is the transfer of resources back to the public. The rub with the Russian privatization was not that 
individuals gained from it (that they would have to for the privatization to be considered successful) but the way it was done and the disregard for equity and fairness associated with the distribution of the spoils. Also, given the institutional setting in which this occurred, the incentives of the new owners were not to run the firm efficiently, but to strip it of its assets.

Stiglitz is right to lay a large part of this blame at the doorstep of the international financial community, which with its larger experience and knowledge base could have avoided the rampant corruption. His description of the loans-for-share scandal is quite chilling. Government took loans from private banks with shares of publicly owned firms as collateral. It then went on to default on these loans and the ownership of public firms had been smoothly transferred over to friendly bank entrepreneurs.

The finer details of the reform package would not have been so important if it were not for the toll it took on ordinary human beings. In 1989, 2\% of those living in Russia were below the poverty line, defined by consumption being less than 2-dollars a day. By 1989 the figure had risen to $23.8 \%$, and $50 \%$ of the children were living in households below the poverty line (Stiglitz, 2002, p. 153).

The story was similar in East Asia. Unemployment rose very sharply within a year-it nearly trebled in Korea; and real wages fell dramatically in Indonesia (by 41\%) but also sharply enough in Korea (9.3\%) and Thailand (7.4\%). This information is summarized in Table 3 below.

We know that in the case of Indonesia this has also led to political instability and violence. For a poor nation, such a sharp downturn has to be quite traumatic.

\footnotetext{
${ }^{16}$ For a survey, see Megginson and Netter (2001). It is however worth mentioning that if the privatization occurs in an environment where there is no appropriate anti-trust legislation, then the privatization can
} 
Table 3

Real Wage and Unemployment Changes in East Asia

\begin{tabular}{|l|c|c|c|}
\hline & \multicolumn{2}{|c|}{$\begin{array}{c} \\
\text { Wage During 1998 }\end{array}$} & \multicolumn{2}{c|}{ Unemployment } \\
\hline & & 1997 & 1998 \\
\hline Indonesia & $-41 \cdot 0$ & $4 \cdot 7$ & $5 \cdot 4$ \\
\hline Korea & $-9 \cdot 3$ & $2 \cdot 6$ & $6 \cdot 8$ \\
\hline Malaysia & $-1 \cdot 1$ & $2 \cdot 6$ & $4 \cdot 0$ \\
\hline Philippines & $-2 \cdot 0$ & $8 \cdot 7$ & $10 \cdot 1$ \\
\hline Thailand & $-7 \cdot 4$ & $2 \cdot 2$ & $5 \cdot 2$ \\
\hline
\end{tabular}

Source: Betcherman and Islam, 2001.

Stiglitz goes on to lament how little the richer nations and power blocks did to assuage the problems, even if we are willing to spare them responsibility for having caused some of the problems. A point that he makes poignantly and more than once is how warped our global policies are that we are willing to spend billions on bailouts, which were often bailouts more for Western banks than for the nations in trouble, whereas, when it came to the few millions of dollars needed to mitigate the degradation and poverty that the crises caused, there was never enough money. ${ }^{17}$ This leads to some large questions of global politics and the way globalization has changed the world. The last chapters of the book take Stiglitz to this large terrain. These are extremely valuable chapters, which no one can afford to ignore. But, at the same time, this is where one is

aggravate certain kinds of inefficiencies (Bhaskar and Khan, 1995).

${ }^{17}$ The one concrete plan that he puts forward for this involves the use of Special Drawing Rights (SDRs) to create global public goods and to help the poor. This is somewhat similar to Soros's (2002) suggestion to 
left regretting that he does not take his power of abstraction and formalization further to organize his thoughts and give us a more complete paradigm of global political economy.

Take, for instance, Stiglitz's criticism of the IMF. Surely, all the faults that he points to cannot be idiosyncratic to the IMF. If that were so, then we would have to simply treat it as an anomaly of nature that this organization is so pernicious. Our prescription would then have to be to excise it or alter its management totally. But that is not what Stiglitz means, since his occasional reference to the U. S. Treasury, The World Bank and the Wall Streeters, shows that the same malaise as the one that afflicts the IMF is widely prevalent. Big powerful organizations all seem to behave in a similar fashion. Hence, the IMF is more a likely a product of the 'system' or the 'rules' of the game by which the global economy runs. Even if the IMF were replaced by a JNG, as long as it functioned in the same global ethos, it would, over time, begin to behave much the same way. My suspicion is that Stiglitz will agree with this analysis ${ }^{18}$. If that be so, the critique needs to be directed much more at the rules of the global game, than at specific players in this game. Policy-wise this is a very hard question. Since we understand so poorly where the fundamental rules of the game of life come from, it is not obvious to anybody how we should go about changing those rules. But given that much of Stiglitz's book builds up to this engaging question, it would have been nice if we could be privy to Stiglitz's thoughts on the matter, however embryonic. I hope that there is another book in the offing. 


\section{Globalization, Politics and Democracy}

One reason why our understanding of global political economy is so weak is because of the way mainstream economics used to be written. Much of it presumed markets to be competitive, information perfect, and human beings fully rational, and there is no room for power politics. Though modern economics has moved far away from that model, especially in terms of recognizing the importance of oligopolies and asymmetries of information $^{19}$, a large number of policymakers remain under the spell of the traditional model. That model may be a reasonable approximation of some simple intra-country markets. But as soon as we enter the global market place, with no overarching system of law and government, we leave the textbook models (even the modern ones, which though rich in other ways is yet to properly characterize the role of power politics in the functioning of economies) behind and looking inadequate. Hence, as is amply clear from this book, there is need to go beyond textbook models - even the modern ones--to a deeper critique and a more fundamental reconstruction of economics that is embedded in sociology and politics.

Let me illustrate this with the far-reaching implication of one assumption that is patently wrong but that most mainstream economics treats as true. This is the assumption of individual rationality. ${ }^{20}$

One major way in which contemporary human beings are better off than humans of an earlier era is that they do not, typically, have to rely on physical strength to guard

\footnotetext{
${ }^{18}$ As he observes in another paper (Stiglitz, 2003), given IMF's mandate and its consequent close connection with various finance ministries and financial communities, it would be surprising to find it behave differently from the way it actually does.

${ }^{19}$ Some of these market failures have been written about effectively by Stiglitz himself in his earlier incarnation as an economic theorist. For a comprehensive review of the ways in which market failures occur in developing countries see Hoff and Stiglitz (2001).

${ }^{20}$ Admittedly the new behavioral economics has at last begun to chip away at this assumption.
} 
their own interest ${ }^{21}$. When we walk down a road wearing a nice watch, we do not have to be prepared to fight to keep it. On returning home from an outing we do not expect to have to throw out people occupying our home. This is because of a general recognition that it is wrong of one person to grab another's belongings just because one is able to, and the consequent policing and social norms that have merged around this recognition.

In primitive times, those who were physically weak must have been reconciled to the fact that the strong would take away much of what was theirs. There may even have been those who argued that that is the way things ought to be. It is a huge achievement in making the world just and fair that this happens no more (at least in most regions).

Note, however, that we do not have an equivalent moral code against one person becoming richer than another by out-witting the latter. Outwitting seems to be fair game. When a rural moneylender becomes rich by repeatedly cutting good deals vis-à-vis the borrower, when a colonizer buys up valuable property from savages, or when a financier extends a home-improvement loan to an old lady living alone in Washington, knowing that the odds are that she will not be able to repay the loan and he will be able to foreclose on her property, we consider these deals acceptable, as long as there is no strong-arm tactic used. If both sides agree freely to a deal, why should anybody else interfere?

What we do not pause to think in these examples is that, maybe, one side is actually miscalculating. Maybe the rural borrower is indulging in hyperbolic discounting and so being dynamically inconsistent, that the savages are being irrational and misjudging the future worth of the property and the old lady, in her eagerness to repaint

\footnotetext{
${ }^{21}$ This is not to deny that there are regions of the world, where the hand of law is so weak that they resemble primitive times.
} 
her home, is being over-optimistic about her capacity to repay the loan. One reason why we have so few safeguards against people cutting irrational deals is because the economists' assumption that all human beings are rational has seeped into our everyday thinking. If no one is irrational, there can be no need to protect the irrational. Deals that look lop-sided must merely reflect differences in preferences.

But now that behavioral economics is beginning to open our eyes, we realize that, may be, some people who are impoverished are so because they cut poor deals over and over again, just as some village lenders are rich because they systematically cut 'good' deals. Likewise there is now recognition that the lady in Washington who gets lured into that attractive loan may be a victim of 'predatory lending'. It is in fact interesting to note that the Federal Trade Commission in Washington now recognizes predatory lending as a problem that needs to be dealt with. ${ }^{22}$

The failure to recognize that outwitting an intellectually weaker person of her wealth may be wrong in the same way that physically unburdening a person of her belongings has had far-reaching consequences, especially in global contexts. First of all, this has meant a lot of unfairness in contracts and, secondly, being aware of the possibility of being 'duped' into signing complex contracts that they do not fully understand (and knowing that the law does not protect them well against such happenings), many individuals and nations have taken the precaution of not getting into deals with savvy business partners ${ }^{23}$. Hence, the lack of legal or norms-based protection ${ }^{24}$ against such possibilities leads to under-contracting and, consequent inefficiencies ${ }^{25}$.

\footnotetext{
${ }^{22}$ See http://www.ftc.gov/opa/2001/02/predlending.htm.

${ }^{23}$ Some years ago in Vietnam I was told by a government official that they hesitate to cut deals with multinationals not because of any inherent aversion to this but for fear that they will not understand complex
} 
Moving on further, observe that even if people were fully rational and there were no problems of information, the global market place would continue to look very different from what textbooks of economics suggest. The reason is the absence of the rule of law and the virtual non-existence of global governance. In much of traditional thinking, especially among those committed to market fundamentalism, governments and markets have been conceptualized as countervailing forces. The advice was always that if you want markets to function properly, governments need to withdraw. Here and in his earlier writings, Stiglitz rejects this proposition (see, for instance, Stiglitz, 1989). Good governance, he argues, is a prerequisite of effective markets. As Soros (2002, p.6) observes, "Markets are designed to facilitate the free exchange of goods and services ... but they are not capable, on their own, of taking care of collective needs such as law and order or the maintenance of the market mechanism itself (my italics)."

Stiglitz argues that on the economic front the world has become interconnected with global markets and money flows; yet global political institutions remain woefully inadequate. $^{26}$ This disillusionment with global political economy can easily translate into a blind mistrust of markets and globalization. The protestors in the streets of Seattle during the ministerial meeting of WTO and protestors elsewhere at various global meetings since Seattle, while rightly upset about the unfairness of the global marketplace,

contracting as well as multi-nationals do and so they may end up signing contracts, unwittingly, that are detrimental to themselves.

${ }^{24}$ In Basu (2000), I argue that the law and social norms can in many situations work as equally effective substitutes.

${ }^{25}$ Before moving on I should emphasize it is not the rejection of the rationality assumption I am arguing for. The assumption has been behind a lot of the success of economics and is very helpful in understanding 'normal' economics. The fault lies in the fact that many economists forget this and take it to domains where its fallibility makes a fundamental difference. This also explains why the new political economy, predicated on the rational actor model, has not met with greater success. I discuss this at length in Basu (2000).

${ }^{26}$ The same sentiment is echoed by Soros (2002, p.9), "While markets have become global, politics remain firmly rooted in the sovereignty for the state." This idea is elaborated upon in Basu (2002). 
have been often blinded by emotion and played into the hands of the very people and groups that they were protesting against. ${ }^{27}$

What is really excellent about this book is that on this main issue Stiglitz manages to have his feet firmly planted on the ground. He makes it amply clear that the potential benefits of globalization are large and that markets and incentives are crucial for the effective running of a modern economy. Our objective should not be to blunt these instruments but to make them work.

So much of the existing popular literature on globalization is so trite because it is based on a critical misunderstanding; it treats globalization as a detachable part of the economy. As if it is something that we can have or we can reject. In reality globalization is a bit like gravity. We may discuss endlessly whether it is good or bad but the question of not having it does not seriously arise. We have to live with it, just as we have to live with gravity (at least in the foreseeable future) no matter what our finer emotions about it are. Not being a detachable part it is very difficult to evaluate it, since the counter-factual of a world like the one we have today but without globalization is difficult to imagine.

If we want to make globalization work in our collective interest (and not alienate large sections of the world, as it has done), what should we do? True, there are not too many answers in this book, but what he does very well is to remind us not to be lulled

\footnotetext{
${ }^{27}$ A classic example of this is the argument for the use of a "social clause" by the WTO to uphold international labor standards (see Bhagwati, 1995). Many protectionist lobbies in industrialized nations favor such a clause (as an instrument to block imports from developing nations), and have nicely managed to mingle behind the banners of well-meaning protestors demanding such a provision in the WTO in the genuine interest of workers in developing countries. Exactly what form the international labor standards requirement will take is a matter of detailed legal and political work and can have very different effects depending on how exactly the provisions are drafted. Since the protesters are usually absent in the crafting of the fine print and the lobbies are usually present, the broad agenda won with the protesters can be converted into a fine print that helps the lobbies instead of the workers.
} 
into believing that all is fair in the marketplace, a point of view that the beneficiaries of the current global economy are eager to promote.

That is not all. He makes another suggestion, briefly, but one that can have farreaching consequences. He argues for a greater democratization of international organizations, so that they become more effective guardians of the interests of the poor nations. Similar arguments have been made by others before (see, for instance, Nayyar, 2003) but coming from Stiglitz, who has been involved with the organizations he seeks to reform, this becomes very compelling. He points out how the United States, Europe and Japan have dominated decisions in the World Bank, the IMF and the WTO, and how it is time to rethink the structure of voting rights in these organizations. ${ }^{28}$

At one level it may seem right that the ones who contribute more money to these organizations should have more say. But given that we do not think along such lines when we talk of intra-national democracy—no one argues that Bill Gates should have more votes than others since he pays more taxes - shows that our notions of global democracy remain quite rudimentary. It is therefore quite radical of Stiglitz to suggest a greater equity in voting rights even in international organizations. He in fact goes to the point of arguing that the rights should not be confined to government ministers, but should, presumably, reflect grassroots opinion as well.

One cannot jump to conclusions on this, since governance needs expertise and, trying to accommodate too many voices can hurt the quality of the decision. On the other hand, the current structure of decision-making, makes it possible for few powerful

\footnotetext{
${ }^{28}$ The WTO runs on the principle of one country one vote, but the fixing of agenda behind the scenes - the so-called 'green room effect'--has tended to concentrate power in the hands of the industrialized nations with a few developing nations, such as India and now China, having some marginal say (Schott, 2000;
} 
interests to hijack the agenda. Moreover, our understanding of the needs of the poor nations itself can improve if the poor nations are given greater voice. ${ }^{29}$ What one can minimally say is that this is a matter that needs to be debated, and not kept away from the public eye in a conspiracy of silence, as is currently done. Hence, Stiglitz's effort at bringing this to public scrutiny is laudable.

\section{Conclusion}

This is a hard book to sum up. It cannot be described as a great book, certainly not by the yardstick of Stiglitz's own earlier papers and books. It brings us to the brink of analytically interesting and novel ideas but stops before breaking new ground. As prose it falls short because it is written too much in the form of streams of consciousness. It would have been nice if the material, rich as it is, were better organized.

But, at the same time, I believe this is an important book, one of the most important that I have read in recent times, and one that must be read by anyone interested in global politics and human well-being, whether one is planning a career in international bureaucracy or to take to the streets. It is a morally courageous books, one in which the author does not flinch from taking on the powerful and the established. It is a book that could have been written only by an 'embedded academic', who has been involved in global policy making, is an acute observer and is irreverent enough to write down what he saw.

Basu, 2002). Some of the poorest nations of the world, such as sub-Saharan African countries, surely deserve more say than they currently have.

${ }^{29}$ This is what Sen (1999) refers to as the "constructive" role of democracy. His discussion is in the context of individual needs in national decision-making. But it clearly carries over to inter-country decision problems. 


\section{References}

Aghion, Philippe, Bacchetta, Philippe and Banerjee, Abhijit (2001), 'Currency Crisis and Monetary Policy in an Economy with Credit Constraints', European Economic Review, vol. 45, 1121-50.

Azis, Iwan, Azis, Erina, and Thorbecke, Erik (2001), 'Modeling the Socio-economic Impact of the Financial Crisis: The Case of Indonesia', mimeo: Cornell University.

Basu, Kaushik (2000), Prelude to Political Economy: A Study of the Social and Political Foundations of Economics, Oxford University Press, Oxford.

Basu, Kaushik (2001), 'On the Goals of Development', in Meier, Gerald, and Stiglitz, Joseph, eds., Frontiers of Economic Development, Oxford University Press, New York.

Basu, Kaushik (2002), 'The Retreat of Global Democracy', Indicators, vol. 1, pp. 77-87. Betcherman, Gordon and Islam, Rizwanul (2001), 'East Asian Labor Markets and the Economic Crisis: An Overview', in Betcherman, G. and Islam, R. (eds.), East Asian Labor Markets and the Economic Crisis, The World Bank, Washington. Bhagwati, Jagdish (1995), 'Trade Liberalization and "Fair Trade" Demands', World Economy, vol. 18, 745-59.

Bhagwati, J. and Tarullo, D. (2003), 'A Ban on Capital Controls is a Bad Trade-Off', Financial Times, 17 March.

Bhaskar, V. and Khan, Mushtaq (1995), 'Privatization and Employment: A Study of the Jute Industry in Bangladesh', American Economic Review, vol. 85, 267-73.

Blustein, Paul (2001), The Chastening, Public Affairs, New York.

Chang, Ha Joon (2001), 'Commentary: Joseph Stiglitz vs. the Wshington Consensus', in Chang, Ha-Joon, ed. Joseph Stigltiz and the World Bank: The Rebel Within, Anthem Press, London.

Hoff, Karla and Stiglitz, Joseph (2001), 'Modern Economic Theory and Development' in Meier, Gerald and Stiglitz, Joseph, eds., Frontiers of Development Economics: The Future in Perspective, Oxford University Press, New York. 
Krugman, Paul (1998), 'I know What the Hedgies did last Summer', Fortune, vol. 138, No. 12.

Madison, Angus (2001), The World Economy: A Millennial Perspective, OECD, Paris.

Martinez, Guillermo O. (1998), 'What Lessons Does the Mexican Crisis Hold for Recovering in Asia?' Finance and Development, vol. 35, 6-9.

Megginson, William and Netter, Jeffry (2001), 'From State to Market: A Survey on Empirical Studies on Privatization', Journal of Economic Literature, vol. 32, 321-389.

Nayyar, Deepak (2003), 'The Existing System and the Missing Institutions', in Nayyar, Deepak, ed., Governing Globalization: Issues and Institutions, Oxford University Press, Oxford.

Rodrik, Dani and Velasco, Andres (1999), 'Short-term Capital Flows', Annual World Bank Conference on Development Economics, 1999, The World Bank, Washington, D.C.

Schott, Jeffrey, ed., (2000), The WTO after Seattle, Institute for International Economics, Washington, D.C..

Sen, Amartya (1999), Development as Freedom, Alfred Knopf, New York.

Stiglitz, Joseph (1989), The Economic Role of the State (edited by A. Heertje), Blackwell Publishers, Oxford.

Stiglitz, Joseph (2002) Globalization and Its Discontents, W.W. Norton \& Co., New York.

Stiglitz, Joseph (2003), 'Globalization and the Logic of International Collective Action: Re-examining the Breton Woods Institutions', in Nayyar, Deepak, ed., Governing Globalization: Issues and Institutions, Oxford University Press, Oxford.

Soros, George (2002), On Globalization, Public Affairs, New York.

Wan, Henry (2003), Economic Development in a Globalized Environment: East Asian Evidence, Kluwer, New York, forthcoming.

Williamson, John (2003), 'The Washington Consensus and Beyond', Economic and Political Weekly, April 12, vol. 38, 1475-81. 